\title{
Neoliberalism and the City ${ }^{1}$
}

\author{
David Harvey, City University of New York
}

It's great to be here and, particularly, to celebrate the beginning of a journal with such an auspicious title. I have long been interested in questions of social justice; one of my first books was Social Justice and the City. For me, it was a revelatory book to write and I hope that it will one day be a revelatory book to read; but sometimes, as in this instance, you learn far more by writing than by reading. My book was about the city and I would like to start with one of my favourite quotations about cities, which is by Robert Park, a Sociologist writing in Chicago in the 1920s. Park put it this way about cities, he said:

The city is man's most consistent and, on the whole, his most successful attempt to remake the world he lives in, more after his heart's desire. The city is the world which man created; it is the world in which he is therefore condemned to live. Thus indirectly, without a clear sense of the nature of his task, in remaking the city, man has remade himself.

You'll have to forgive the gender bias in that quotation, it was written in the 1920s. For me, the significance of this statement is something that needs to be reflected upon; because I can be accused of liking it but also because in some ways it parallels a famous statement by Marx. In Capital, Marx talks about the process of human labour and he makes the dialectical point that we cannot change the world around us without changing ourselves and we cannot change ourselves without changing the world around us. And so Marx sees the whole of human history as being the working out of the dialectic of transformations of who we are and what we are, along with the transformation of the world around us, the environment and everything else. Park, of course was not a Marxist, I doubt if he ever read Marx, but Park is making the same argument. The implication of Park's argument is that the question "what of kind of cities do we want to live in" cannot be divorced from the question of "what kind of people do we want to be," "what kind of humanity we wish to create amongst ourselves," and "how do we want to create it?" It is that mutual constitution of the city, of who we are and what we are, that is something which I think it is very important to reflect upon. Particularly since we look back historically and ask, were we ever conscious of this task? Were we ever conscious that we were doing this? I think the answer is that as the cities changed, we changed without us really being very conscious of it.

Occasionally someone would come along, a utopian usually, and say; "Hey, we should make a different kind of city. And this different kind of city is going to be the kind of city where we are going to be wonderful people, instead of the all the evil nasty people we see around us." So there is a utopian tradition which tries to answer Park's argument, by becoming conscious of the task and making proposals about city forms and city

\footnotetext{
${ }^{1}$ This is a transcript of a lecture given at the University of Windsor on September 25, 2006.
} 
functions and city growth which is somehow connected to the idea of creating an ideal human community, an ideal world in which we can live. Most utopian schemes have never worked very well, for reasons that I will not go into here. But when we look back historically and geographically about the way in which New York was built, Toronto was built, Birmingham was built, Moscow was built, Shanghai was built, it isn't as if those places were built with the very distinct idea about what kind of people we wanted to be. But the result of that urbanization has been the creation of a certain kind of human society, and we have to pay attention to what kind of human society this is.

There is a very old saying from the medieval periods, it says the "city air makes one free," and it is here that the idea of the freedom of the city starts to be important historically. A question I want to reflect upon today is "what kind of freedom do we have in the city?" Right now, if we say "city air makes us free” what kind of freedom is being constituted by the urban processes that are going on around us? These questions lead immediately to the questions "what do we mean by freedom," "who is in a position to tell us what this freedom is," and "how do we designate what this freedom is?" Of course we have a tremendous ethic for this idea called freedom.

South of the border, a man called George Bush has actually done a lot of writing, many speeches, on this theme about liberty and freedom. I am so curious about this so I actually took time off and re-read all of George Bush's speeches and they're very interesting. He says a number of different things. On the anniversary of $9 / 11$, he said:

We are determined to stand for the values that gave our nation its birth, because a peaceful world of growing freedoms serves America's long term interests, reflects enduring American ideals, and unites America's allies. Humanity has the opportunity to further freedom's triumph over its age-old foes.

He goes on to say that the "United States welcomes its responsibility to lead with this great nation." These sentiments could be found before 9/11 in some of George Bush's speeches-they were not new. There is an interesting addendum. When Tony Blair came to address Congress, in July 2003, he proposed a friendly amendment to George Bush's emphasis on American values. He said:

There is a myth that, though we love freedom, others don't, that our attachment to freedom is a product of our culture, that freedom, democracy, human rights, rule of law, are American values or western values. Members of Congress, ours are not western values; they are the universal values of the human spirit.

Bush accepted this amendment. In his next speech which was delivered in Westminster in answer to Blair's speech, he said:

The advance of freedom is the calling of our time. It is the calling of our country from the 14 points [and here he is referring back to Woodrow Wilson], to the 4 freedoms [referring to Roosevelt], to the speech of Westminster [here talking of Ronald Reagan]. America has put its power 
in service of the principle that we believe that liberty is the design of nature, we believe that liberty is the direction of history. We believe that human fulfillment and excellence come with the responsible exercise of liberty. We believe that the freedom we prize is not for us alone, but the right and capacity for all mankind.

At his acceptance speech at the Republican National Convention in 2004, George Bush said:

I believe America has been called to lead the cause of freedom in a new century. I believe that millions in the Middle East plead in silence for their liberty. If given the chance they will embrace the most honourable form of government ever devised by man. I believe all these things because freedom is not Americans' gift to the world, but the Almighty's gift to every man and women in this world.

In his Inaugural Speech in January 2005, he said:

We can afford complete confidence in the eventual triumph of this world. Not because history runs on the wheels of inevitability - it is human choices that move, advance - not because we consider ourselves a chosen nation-God moves and chooses as he wills. While history has an air of justice it also has visible direction set by liberty and the author of liberty.

There is an interesting set of transitions in these speeches. From the idea that freedom and liberty are American values, to the idea that they are universal values, to the idea that they are values imbedded in nature, to the idea that they are, of course, part of the intelligent design of the Almighty for the earth. What is interesting about this rhetoric is that it is persistent in the Bush Administration. We can take two approaches to it. One is to say this is just hot air, it is hypocritical nonsense. When we look at Guantanamo Bay or Abu Ghraib, when we look at all the things that are going on on the ground, we are horrified that there is an incredible mismatch between this rhetoric about liberty and freedom and the facts of what is occurring in the actual policies as they are unfolding. Even in the Patriot Act in the US, the authoritarianism that we are seeing at all levels of government-this rhetoric is completely false and hypocritical and this is the wrong way to interpret it. I think it is wrong for a number of reasons. Bush sticks very much to his claims of liberty and freedom. The conservative columnist David Brooks of the New York Times made this comment and I think I partially agree with him, he says:

We should not assume that America is the money grabbing, resource wasting, TV drenched, unreflective bimbo of the earth and all this hightoned language is just a cover for the quest for oil, for the desire for riches, dominion, or war.

I actually think America is all those things, but what Brooks is quite right about, is to say that it is not just all of those things. The ideals of Bush are, in fact, deeply embedded in American history and are very, very significant to the way in which people in the US 
construe their positionality in the world. We need to find the power of this rhetoric, the significance of this rhetoric, and the tradition of this rhetoric. When for example, Bush referred back to Woodrow Wilson he made a very, very powerful connection. Woodrow Wilson (a Liberal) was concerned with liberty and freedom in the world. At the same time, he was up against somewhat more grubby concerns. For instance, Woodrow Wilson put it this way when he was President:

Since trade ignores natural boundaries and the manufacturer insists on having the world as a market, the flag of his nation must follow him and the doors of the nation which are closed against him must be battered down. The concessions obtained by financiers must be safeguarded by ministers of state, i.e. the military, even if the sovereignty of an unwilling nation has been outraged in the process. Colonies must be obtained or planted, in order that any useful corner of the nation does not go overlooked or is left unused.

Roosevelt had similar global designs. Reagan of course, also similar. Now I want to make this point because there is an erroneous view that Bush is an aberration in the American tradition. He is not; he is firmly implanted in that tradition. Therefore we cannot entertain the notion that simply voting Bush out of office and putting somebody like Clinton back in is going to solve the problem.

Now this idea of freedom is very important, but we have to put some tangible meaning to it. The way that Bush set up the tangible meaning is by simply associating again and again in his speeches the idea that freedom is represented by the freedom of the market and freedom of trade. What Bush meant by freedom is best signalled by what Paul Bremer, head of the Coalition of Provisional Authority in Iraq, did before the handover of government. There was a complete reconstruction around the institutional arrangement of the Iraqi state. The privatization of everything was mandated. There should be no barrier to private ownership. There should be no barriers to foreign investors coming in and doing as they please, no barriers on the properties of the country, no barriers to trade. In effect what Paul Bremer did, before he handed over authority, was to lay out a whole set of provisions in the Iraqi institutional arrangements which were consistent with a neoliberal state apparatus. A perfect fit with the WTO and also the theory of how a neoliberal state apparatus should look. There were something like 70-80 provisions, decrees that Bremer left with the Iraqis. When they handed over government to the Iraqis, it was a condition of handing it over that they could not change anything. So, the Iraqis were invited to take this idea of freedom in a certain vein. The critic Matthew Arnold made a comment a long time ago, "Freedom is a great idea, it is a great horse to ride, provided you know where you're riding it to.” What the Iraqis were invited to do was to ride the horse of freedom right into the neoliberal corral. The Iraqi constitution that was set up in 2003 was almost identical to the constitution that was arrived at 30 years ago, in 1975 to be exact, in the wake of the coup in Chile which got rid of Salvador Allende and put Pinochet in charge. There was a two year hiatus in Chile because the question was, what kind of economic program would revive the economy? What they did in Chile was bring in the Chicago Boys who said, "Privatize everything, open up to foreign investment, foreign trade, no barriers to repatriation of private property, have an export 
led growth model.” Of course they didn't have to discipline labour because all the labour leaders were dead, all trade unions were dismantled. All healthcare clinics where radical opposition had fermented were dismantled. There was a completely neoliberal regime implemented in Chile in 1975, which was absolutely identical to the one the US imposed upon Iraq in 2003.

So, again, there is a certain conception of freedom that is emphasized. I think what happened after the Chilean coup and what happened in Iraq brackets a whole historical theory in which strong processes of neoliberalism have transformed the world, transformed us to the point that all of us are neoliberals, whether we like or not. All of us have absorbed the ethos of neoliberalization, and, as a result, we relate to each other in very different ways. We see this change most spectacularly in the ways that cities have been transformed during this period. For me, one of the most fascinating things has been to track neoliberalization back to New York City in 1975. This is exactly the same time that the coup was occurring in Chile.

New York City went bankrupt in 1975. The bankruptcy of New York City was a singular event that had dramatic global consequences. To begin with, New York City's budget was one of the largest public projects in the world. It was either the $14^{\text {th }}$ or $15^{\text {th }}$ largest public project in the world. So bankrupting something of this kind would be tantamount to bankrupting a country like Italy or France. The idea was so potentially damaging, that the West German Chancellor and the French President both appealed to the Ford Administration and said "you can’t let this happen.” But it did happen and what happened after it was absolutely crucial.

Why and what happened? During the 1960s New York City had been losing jobs and companies had been moving out to the suburbs or out to the American South (not yet going to Mexico, Taiwan, or China, but they were moving out). As a result, industrial employment was declining in New York City. Of course, this was going on in many American cities at the time. The result was that the centre of cities was occupied by disaffected, unemployed, marginalized and very often racially marked populations. These rose up in a variety of crises in the 1960s and it became known as the Urban Crisis of the 1960s.

Riots, particularly the ones that followed the assassination of Martin Luther King in 1968 created mayhem in many of the central cities. The federal government was determined to do something about it. It decided it would try to help central cities recover; it set in place a recovery program. The recovery program largely rested on the expansion of the public sector. The public sector expanded because federal funds were flying into the cities, very fast, and municipal governments could start to expand their workforces and expand the services they offered. There was expansion of education, expansion of healthcare, expansion of garbage collection, and expansion of transit workers. The New York City municipal sector expanded very rapidly during the late 1960s and early 70s as part of this stabilization program. This program also involved integration of racial minorities into the labour force through public employment. The whole program depended on the city having adequate finances. The city did not have adequate finances and therefore started to borrow heavily in the late 1960s and early 1970s. The investment bankers loved it because, New York City had a big budget therefore it was a secure investment. The investment bankers were very happy to fund all of this. In fact, they even taught New York City slippery games, creative accounting and all those kind of things, so

Studies in Social Justice, Volume 1, Number 1, Winter 2007 ISSN: $1911-4788$ 
they could get financed in more "sophisticated" kinds of ways. But, in 1973, things started to go bad. The city started to lose money, property taxes were in decline, and incomes were declining. And in 1973, the federal government found itself in a financial crisis. I will always remember the day when President Nixon came on the radio for his State of the Union Address and said, "The urban crisis is over." I looked out the window and said, "Wow, Baltimore looks the same to me." I thought people would be dancing in the streets. It was the same kind of grubby, messy, horrible kind of place, declining as it always had been. What Nixon meant by this was, "We are not going to give you any more money." They stopped giving money to New York City. Budgets were cut back without federal money coming in. So New York City started borrowing even more. In 1975, the investment bankers said "No, we are no going to lend you any more." It was a dramatic moment when the city administration said, "What? What are we going to do?" The investment bankers said, "We don’t know." So this is part of the story.

The second part of the story is this, during the 1960s and 1970s, there had been a program of what I call "surplus capital." There was too much capital around and no one knew what to do with it. A lot of went to real estate speculation. There was a huge building boom in many American cities and particularly New York City. This is the time that produced the World Trade Center, which was an economic disaster because nobody ever wanted to locate in them and they could never be filled with regular tenants at all. There was a building boom and the most incredible overbuilding, particularly in the office sector. The city was also doing all kinds of things such as forgiving property taxes. It was a real game being played with developers around the property market. The property market crashed in 1973. There were all these empty buildings around, not paying taxes, and this was a part of the problem for New York City. So between the shortage of employment and the lack of property taxes, you had this crisis. But there is another issue, why did the investment bankers suddenly decided not to lend? If you look at an economy that is grossly in debt, is being fiscally managed in an appalling way, where all of the indicators suggest that you shouldn't lend to them anymore, you are looking at the contemporary United States. The aggregate data on New York City back then is no worse than the aggregate data on the whole US economy right now. And the equivalent right now would be the Chinese Central Bank, Japanese Central Bank, and the South Korean Central Bank, suddenly deciding "We are not going to lend you any money anymore.” There would be no money in the United States to fight the war; no money to spend on this property boom, all this consumerism; no money to run the huge deficit which we are running. The question is why did the investment bankers in New York City suddenly decide not to lend? It seems to me, that this is the real story of the fiscal crisis of New York City. Clearly New York City was vulnerable, what was New York City doing that the investment bankers didn't like? What they were doing was playing nice to the unions, they were actually spreading the money around, and they were engaged in all kinds of philanthropic projects, actually being nice to minorities, black people, and all the rest of it. The city was doing all kinds of things that stood in the way of the ambitions of men like David Rockefeller who wanted New York City to be an island for bourgeois affluence. At the same time that the monies were being pushed, there was a lot of antibanker sentiment in the city and a lot of anti-corporate sentiment in the city.

Remember, this was a time when students in Santa Barbara actually buried a Chevy in the sand and burned down the Bank of America building. There was a lot of

Studies in Social Justice, Volume 1, Number 1, Winter 2007 ISSN: 1911-4788 
radicalism, a lot of anti-corporate politics. Big businesses were getting nervous at the beginning of the 1970s. They started to work together to try to recreate a viable corporate capitalism that would have significant power. New York City was heading towards becoming a social democratic, almost socialist, kind of municipality. The big businesses were terrified politically. So they launched a financial coup against the city. My argument is that this financial coup against New York City was just as effective as Pinochet's military coup in Chile. But, what now had to happen was New York City had to be disciplined into a new kind of economic future. How are you going to do that democratically? One of the things that happened immediately was that all authority over the budget was taken away from the elected officials and given to the Municipal Assistance Corporation (MAC), later called the Emergency Financial Control Board. The MAC was run by the investment bankers, a couple of representatives from the state, and a couple of representatives from the city. What they did, in effect, was take all of the receipts coming into the city, all the taxes, and they said, "We'll take all this money and the first thing we'll do is pay off all the bondholders; pay off all those holding the debt. Whatever is left goes into the city budget." Well you can imagine what that meant for unemployment and cuts in services. It was a catastrophe. They even insisted that the municipal unions put their all their pension funds into the debt. So, if the municipal unions created any kind of problem and New York City went bankrupt they would lose all their pensions. It was a very clever move for that time.

It was here, I think, that an extremely important principle that became a global principle was first enacted. If there is a conflict between the well being of financial institutions and the well being of the population, the government will choose the well being of the financial institutions; to hell with the well being of the population. This of course became the gospel of the International Monetary Fund (IMF) and their Structural Adjustment Programs (SAPs) that began in the 1980s; one of the first ones was Mexico. The MAC disciplined the city, it attacked the workforce, and it attacked social expenditures of all kinds. But, the investment bankers had a problem; their problem was that they had all this property. So they couldn't walk away from the city and say "the hell with it," they had to revive the city and discipline it at the same time. This situation was really hitting the services. Garbage was not being picked up; they had to come up with a strategy to revive the city so that the value of all those properties that had been negative in the 1970s would come back online.

How did they do this? They did it in two ways. The first was an international ploy. One of the things that happened in 1973, if you recall, was a huge rise in oil prices as OPEC kicked in and there was an oil boycott. The price of oil shot up resulting in petrodollars accumulating in the Gulf States. Saudi Arabia suddenly found itself with tons and tons of dollars, as did all Gulf States. The big question was what were they going to do with all that money? Stick it under the mattress? What we now know from British Intelligence reports which were just released last year, is that British Intelligence reckoned that there was a strong possibility that the US was going to invade Saudi Arabia in 1973, in order to occupy the oil wells and bring the oil prices down. We know that is how far planning went. We don't know if this was just a contingency plan, or how serious it was. Nobody knows; we likely won't know for a long time. What we do know, is that the US Ambassador to Saudi Arabia went to the Saudis and raised the question of what they were going to do with their petrodollars. They negotiated an exclusive arrangement 
with the Saudis that Saudi Arabia would recycle their petrodollars through the US investment banks. Whether the Saudis knew they were going to be invaded or not, or whether they knew they were going to be bombed to the Stone Age, I don't know. But, we do know that the Saudis agreed to take all of those petrodollars, give them to the New York investment banks, which gave them a tremendously privileged position, in terms of global finance. It assured that New York City became the financial capital of the world. And we often think that New York City is the financial capital because it seems natural. Well it's not natural; it's partly US military power that assured it. So, the New York investment bankers had the money, they had the business. They were going to have lots of employment in financial services in New York City. Manufacturing in the city didn't matter. They had to remake the city around financial services and all the things that come with it.

So at that time, the investment bankers and the corporations got together, around the idea of reviving the economy of New York City. They set up something called the Downtown Business Partnership. That partnership decided that they are going to sell New York City as a destination for anyone interested in culture; they really pushed the cultural institutions like the Museum of Modern Art, Broadway, and other institutions as a destination for consumption, as tourist destinations. This is the moment that they came up with the logo, which you have all seen, “I Love New York.” They were going to sell the city; this is how they were going to revitalize it. But how could they do that at a time when nobody was picking up the garbage? Why would tourists come to the city when there was garbage on the streets? So, they had to start to actually deal, hands on, with how city government was working, in the process they came across serious resistance. The police and fire unions were outraged that their wages were being diminished, their contracts were being revoked, and a lot of them were being laid off. So they launched a campaign against the "I Love New York" idea. They produced a pamphlet called "Fear City.” They went to Kennedy Airport and gave it to tourists. It said things like "Don't go to the city, because if there is a fire in your hotel, you will have to jump out the window because there are no fire people to get you out," "don't walk in the city," "you can only use the buses between 9 o'clock in the morning and 5 in the afternoon," and "never go on the subway because you're going to get mugged." So they launched this "Fear City" campaign that actually got back to Europe and European travellers were kind of saying "I don't think I can go to New York." This was the time when other things were going on like the Summer of Sam, grisly murders, and things like that. Clearly the Downtown Business Partnership had an image problem. So it negotiated with the police and fire unions and said "Call off this campaign and we'll re-hire a bunch of you." So they said "OK" and called off the campaign and a bunch of them were rehired. But they were assigned to work in Manhattan. So the Bronx burned down, a lot of the Queens garbage was never picked up, and a lot of crime was going on all over the place. But they sealed off Manhattan and made it a privileged place. Manhattan was as safe as they could possibly make it. It wasn't very safe in the 1980s, it was really pretty rough, but bit by bit there was a reoccupation of Manhattan.

So this was the second principle: the municipal government was no longer about benefiting the population, the municipal government had to address creating a good business climate. That was the goal, create a good business climate. And if there is a conflict between creating a good business climate and the well being of this or that 
segment of the population, then to hell with this or that segment of the population. New York City became a divided city in the 1980s; an incredible crime wave took over. If you are going to privatize everything, why not privatize redistribution through criminal activity. That, in effect, is what began to happen. The only problem was, given the way in which the defences were being set up, that it became increasingly difficult to privatize the very rich. They could only do it with poor people, or middle class people. The other problem was, of course, that the other New York, the one that was not being privileged, had a crack epidemic, an AIDS epidemic and a public health crisis. So half of the city was suffering miserably, while the other half was being steadily built up by business partnerships and a privileged notion of "this is a Manhattan we know and love."

Now we come to an end point of that, right now in the Bloomberg Administration. Here is a man who is a billionaire, who's basically bought his way into the Mayoralty, and actually he is not a bad mayor. He's not as bad as some of the mayors who have been around and he really is concerned about trying to make New York City competitive in the global economy. But, competitive for what? One of the first things Michael Bloomberg did was say "We're not going to offer any subsidies to corporations to come here." He went on record as saying, "If a corporation needs a subsidy to locate, in this high cost, high quality, wonderful location of New York City, if they need a subsidy to come here, then we don't want them. We only want corporations that can afford to be here." He didn't say that about people, but, in fact, that policy carries over to people. There is an out migration from New York City of low income people, particularly Hispanics. They're moving to small towns in Pennsylvania and upper New York State because they can't afford to live in New York City anymore. Conditions of life for them in New York City are appalling. Meanwhile, the conditions of life for the very, very rich are absolutely wonderful. This is the kind of city I now live in. On the one hand, you can appreciate living in an environment like Manhattan, which is relatively safe now, where services are not bad at all. You can appreciate that, but the trouble is that for middle class people such as myself it is becoming impossible to live in Manhattan anymore, and part of that has to do with the trajectory that neoliberalization has taken.

I mentioned investment bankers getting all this money from Saudi Arabia, the question is, what were they going to do with it? The US economy was depressed, where were they going to lend the money? They couldn't put it into new buildings in Manhattan; there were too many buildings around anyway. There was a real problem of surplus capital in 1975. Where on Earth they were going to put this surplus money? Walter Wriston, one of the investment bankers, said "its simple, we lend to countries, because countries don't go away, we can always find them." So they started lending massive amounts of money to places like Mexico, Brazil, Argentina, even Poland. They lent on relatively low interest rates because interest rates were very low in the 70s. Then Paul Volcker suddenly raised all the interest rates because of the higher rate of inflation in 1979. When the interest rate rose, suddenly Mexico had to pay back at a higher rate of interest and they couldn't pay. So Mexico went bankrupt in 1982.

The right wing neoliberals don't like the IMF. In the first year of the Reagan Administration, James Baker drew up a plan to effectively abolish the IMF and the Reagan Administration was going to do it. Except that Mexico went bankrupt. There was a real problem, if you let Mexico go bankrupt, then whose loans are going to be hit, Citibank, Chase Manhattan, all the New York banks were really going to be seriously hit 
by the bankruptcy of Mexico. So it was at this point that they decided that they were going to rescue Mexico. They had to rescue Mexico. Well, the US Treasury stepped in and at that point James Baker suddenly said, "Ah this is where the IMF can help and they can do the dirty work for us." The trouble was that at that time the IMF was constituted by Keynesian thinking people. So the first thing Baker said was, "let's appoint someone who is a true blue monetarist neoliberal and put them in there." So they had what Joseph Stiglitz calls a "purge of all the Keynesians out of the IMF and World Bank in 1982." They brought in all these other economists who were thinking in terms of monetarism and neoliberal principles. Then they said "let's do the Mexico thing." What the IMF started to do was to engage in this process by saying "The way to get the money back from the Mexicans is to put the squeeze on the Mexican people. Again, it is that principle which was established in New York City that if there is conflict between the financial institutions and the well-being of the people, hit the well-being of the people of Mexico, hit the well-being of the people of Brazil, hit the well-being of those in Ecuador, hit the well being of wherever it is. Structural adjustment does exactly that. At the same time it also insists on institutional reform, "get rid of strong unions, introduce flexibility into the labour market, and reform your pension structures," so that structural adjustment becomes the name of the game. This is the way in which the IMF started to work globally and the New York investment banks, at the centre of that, have, of course, become incredibly affluent. What's more, they have become engaged in the process of financialization on a global scale.

New instruments, some of them quite astonishing, have begun to emerge. Hedge funds for example, there were about 300 of them 15 years ago, now there are something like 3000 of them. We've seen recently one of them going belly up and things like that but, still, the leading hedge fund managers last year personally took 250 million dollars each. That is, they each had a personal income of 250 million dollars in one year. Now I know you are all going to have ambitions of becoming hedge fund managers, but watch out, watch out. That's not uncommon in the financial services industry. In Manhattan we have lots of people like that living in the place, a privileged centre, for a trans-national capitalist class, if you want to call it that-I don't like that term though — to enjoy itself, to manipulate monies which are fictitious. This last weekend in the New York Times there was some data on some interesting aggregates that are coming out recently. There are things called interest rate and currency derivatives. We can talk about what they are, and if you know what they are fine, and if not what you need to know is that in 1988, these were zero. Now they are 250.8 trillion dollars. There is something called "credit default swaps" and the volume of them outstanding stood at zero in the year 2000 and now its 26.0 trillion dollars. Equity derivatives outstanding in 2002 were about 2 trillion dollars, now there about 6.4 trillion. The article comments that the total of all these outstanding swaps and derivatives at the end of June was 283.2 trillion dollars. The combined gross domestic product of the United States, the European Union, Canada, Japan, and China is 34 trillion dollars. These people are making masses and masses of money out of playing these games, these fictitious games and it's all over the city. The city of New York is now dominated by that kind of wealth which is generated out of this kind of activity. Of course a lot of that wealth trickles down, not to people like me, but it trickles down to financial services in general; it trickles down to the legal services, tax avoidance. I know someone who just retired who is getting 400,000 dollars a year,

Studies in Social Justice, Volume 1, Number 1, Winter 2007 ISSN: $1911-4788$ 
working part time. What does he do? He advised people how to play the tax game, internationally. This is, of course, what neoliberalization has been about. When you look at the aggregate data, and it's absolutely astonishing, the top one percent of the US population has doubled its share of the national income over the last twenty years. This has happened in Britain too, and other places where neoliberalization has taken hold. The top 0.1 percent has quadrupled its share of the national income over the last twenty years. But when you go to the top 0.01 percent, they have increased their income by 497 percent over the last twenty years. All you have to do is start looking at this data and you will realize there is an incredible concentration of wealth occurring in any country that goes neoliberal, part neoliberal, or major neoliberal. China, right now, has gone a peculiar kind of neoliberal. The amount of wealth that is being concentrated in a few hands in China is absolutely astonishing also.

What this leads to is the general idea that neoliberalization, from its very inception, was about the restoration of class power and, in particular, the restoration of class power to a very privileged elite, i.e. the investment bankers and top corporate chiefs. The data show that again and again and again. At this point you have to say that this was a conscious policy, this was not an accident. It is kind of funny, you read all these accounts of people like Stiglitz in the 90s, and he said, "well we did this policy and that policy and it's interesting that the rich got richer and poor got poorer by accident, but that was just a by-product of what was happening." No, that's what these policies were designed to do all along, that's exactly what they were doing in New York City. Since Mexico went really neoliberal after the IMF had done several rounds of going after it, the World Bank also, it went really neoliberal between 1988 and 1992. Five years later, there are something like 20 Mexicans on the World's Wealthiest List. I believe that the third or fourth richest man in the world is a man called Carlos Slim, who is Mexican. Mexico has more billionaires than Saudi Arabia. For those of you who have been to Mexico, have you noticed that there is poverty there? Have you noticed there is a lot of unemployment there? Have you noticed there is a lot of misery there? A lot of ill health and no public services, the water is dirty. This is what neoliberalization is all about and what it does to cities is really fascinating. In the New York case, neoliberalization was followed by an enormous crime wave and ill health wave, which was followed by the Giuliani repressions. Actually if you look at all Latin American cities in the neoliberal period, all of them have had an increase in the absolute level of poverty, except Santiago. All of them, including Santiago, have had an incredible increase in social inequality. The result of that is that we now have divided cities; gated communities here, impoverished communities there. The city is being dissolved into micro-states of rich and poor. We have that in New York City, with Manhattan vs. the Boroughs still. The other thing the data show about Latin American urbanization is an enormous crime wave that has racked the cities to the point where criminal gangs have taken over the streets of Sao Paulo periodically over the last few months and shown that they can run the city. You find criminal activity, armed robberies. I go to Argentina regularly because my wife is from Argentina. Last Christmas we had the pleasure of lying on the floor face down, guns pointed at us, while they took everything. And this is normal, this is not abnormal, this is normal. This is the privatization of redistribution of income; I think you have to understand it that way.

Studies in Social Justice, Volume 1, Number 1, Winter 2007 
So the big concern is, through the evolution of these cities look at what's going on. There is literature now like Mike Davis' Planet of Slums, and we are talking about that. We have to get a grasp of the process, where it's coming from, who's doing it and what's doing it. In order to get a grasp, we have to come back to some simple strategies. If it looks like class struggle, feels like class struggle, then it is class struggle for God's sake! And the only way you're going to deal with it is to fight back in class struggle terms. But, I'm told by my academic friends that class is no longer a valid category. I'm told by others of old, that it's disruptive. If you talk about class, you "rock the boat." The Wall Street Journal sneers at anybody who talks about this redistribution and says "Oh they want to launch a divisive class struggle," as if we are all together in the same boat. We are not all together in the same boat. I am not in the same boat as those that take home 250 million dollars in a year. So this, it seems to me, is where we're at. In order to do something about it I think we have to recognize that cities have always been centres of conflict, change and transformation. There are, actually, movements at work in different cities trying to change things. You can look at stuff that is going in various Brazilian cities and what's going on in some European cities. Cities can be crucibles where new politics can be constructed and emerge. The biggest difficulty right now is that cities are being divided into microstates. So that even now I'm told that "the city" is not a valid concept either. My answer to that is we have to regain some notion of the city, in the way that Park is talking about, as some kind of body politic through which we can reconstruct, not only cities, but can reconstruct human relations and ourselves. We have to think about it in those terms, and we have to understand that this is a political project, a class project. Otherwise we will simply go through the next round of restructuring and find ourselves passively agreeing to what is going on. It is with that idea that I'd like to leave you and hope that this will be one of the big themes that you will take up in your new journal. 